\title{
Notes from the Underground
}

I am most pleased to see that so many of you have returned to read the second edition of our new journal. We have prepared for you a veritable feast of articles designed to entertain as well as to educate. Although thematic issues were never part of our original plans for this magazine, several of the writings here assembled for your pleasure might be thought of as having been inspired by Cleo, the muse of History (and one of my own distant cousins). One of these will transport you back to the world of the Ancient Celts — via the rich domain of ancient literature and modern archaeology, not the tawdry realm of cheap fiction (those of you wearing 'celtic' pentacles, kindly take note). In another we will examine the development, over the last century and a half, of today's widespread belief in a pan-European, monotheistic Great Goddess of the Neolithic. A third piece began life as a kind of obituary (an art form honoured in my kingdom), but it grew, not an unusual thing in my realm of Change, into a kind of capsule history of the early days of the Craft in North America.

In addition to these, we present another installment of our advice column as well as a review of two new, and most welcome, books on the creation of rituals and ritual space.

One thing that you will not, alas, find in this issue is a column of Letters to the Editor. Those of you, dear readers, who enjoy participating in the exchange of ideas are encouraged to take virtual pen in hand and begin this process by writing letters to us at once. My hard-working minions eagerly await your input.

We hope you find this issue as intriguing as the last, and we trust that you will also eagerly look forward to our third issue — three being an important number in my kingdom, both of magazines and of pomegranate seeds. We bid you welcome to our table: please subscribe; tell your friends; write articles; write letters ... and do have some more of this divine fruit, my dears! 